\title{
PHENOTYPIC MODELS OF COMPETITION FOR Pinus taeda L GENETIC PARAMETERS ESTIMATION
}

Keywords:

Spatial analysis

Covariate

REML/BLUP

Components of variance

Historic:

Received 23/05/2017

Accepted I / /09/2017

Palavras chave:

Análise espacial

Covariável

REML/BLUP

Componentes de variância

${ }^{+}$Correspondence: vanessa.ishibashi@gmail.com
ABSTRACT: The objective of this study was to evaluate the efficiency of the phenotypic models of competition, through spatial analysis in the genetic evaluation of Pinus taeda $\mathrm{L}$ progenies. For this, four competition covariates were used to adjust the phenotypic values in a $P$. taeda progeny test installed in four different locations in the state of Santa Catarina. The test was implemented in randomized block design, with seven repetitions, linear plots containing six plants per plot in $2.5 \mathrm{~m} \times 2.0 \mathrm{~m}$ spacing. The test installed in sites A, $B$, and $D$ present 63 families and site $C 53$ families. At nine years old, the diameter at the breast height was measured for all individuals. The presence or absence of competition was based on the residual autocorrelation coefficients, which had its significance tested by the Durbin-Watson test. In general, the use of covariates corrected the competition effect. The variances among and within plots, as well as the residual variation coefficient, were reduced. The classification by the genetic effect of the individuals in the progeny test was extremely altered for this data set with and without the use of covariates for sites $A$ and $D$, as well as the genotype $x$ environment interaction. The use of these two tools is of great importance in the analysis of data in P. taeda progeny tests, since the effects of competition can lead to mistakes in the selection of individuals and in the definition of improvement zones.

\section{MODELOS FENOTÍ́PICOS DE CONCORRÊNCIA PARA Pinus taeda L ESTIMAÇÃO DE PARÂMETROS GENÉTICOS}

RESUMO: O objetivo foi avaliar a eficiência dos modelos fenotípicos de competição, via análise espacial, na avaliação genética de testes de progênies de Pinus taeda L. Para isso foram utilizadas quatro covariáveis de competição para ajuste dos valores fenotípicos em um teste de progênies de $P$. taeda plantado em quatro diferentes locais no estado de Santa Catarina. O teste foi implantado em delineamento de blocos casualizados, com sete repetições, parcelas lineares de seis plantas e espaçamento de $2,5 \mathrm{~m} \times 2,0 \mathrm{~m}$. $O$ teste instalado nos locais A, B e D possuem 63 famílias e no local C 53 famílias. Aos nove anos de idade foi efetuada a mensuração da variável diâmetro à altura do peito de todos os indivíduos. A presença ou não da competição foi baseada nos coeficientes de autocorrelação residual, que teve sua significância testada pelo teste de Durbin-Watson. No geral, o uso de covariáveis corrigiu o efeito da competição e as variâncias entre e dentro de parcela e o coeficiente de variação residual foram reduzidos. A análise espacial foi apropriada para validar a eficiência das covariáveis. A classificação pelo efeito genético dos indivíduos no teste de progênies foi extremamente alterada para o conjunto de dados com e sem o uso de covariáveis para os locais $A$ e $D$, assim como a interação genótipo $x$ ambiente. $O$ uso dessas duas ferramentas é de suma importância na análise de dados em testes de progênies de $P$. taeda, pois os efeitos de competição podem conduzir a erros na seleção de indivíduos e na definição de zonas de melhoramento. 


\section{INTRODUCTION}

Biological variation is the basis for the breeder's work genetic improvement programs of forest species, the most widely used way to distinguish between environmental and genetic variability is progeny testing. This allows to estimate genetic and phenotypic parameters and to predict the genetic value of a specific set of individuals. These tests are commonly established in small linear plots, ranging from four to nine plants (STOEHR et al., 20I0). This way, there is an increase in statistical efficiency, since they reduce the variance within the block, but increase the interaction between neighboring individuals due to the competition (LEONARDECZ-NETO et al., 2003).

Competition is caused by genetic and environmental factors and is due to genotypes and the spatial arrangement of neighboring trees (CAPPA et al., 2016). In forest field trials, it is mainly caused by the lack of space induced by high intraspecific density (LEONARDECZ-NETO et al., 2003). In which the growth of the individuals of the plot is correlated to its neighbors, due to the common micro environment (PAVAN et al., 20I2). In linear plots, this competition can occur within the plots (inter-genotypic competition) or between the experimental plots (intragenotypic competition).

However, in the models used for analysis of progeny tests, it is not common to consider the effects of competition, as there are no established routines; and the definition of specific methods to correct this type of interference (PAVAN et al., 20I2), this implies in the reduction of the ability to identify the genetic variation and the precision of the genetic value prediction (YE and JAYAWICKRAMA, 2008).

This interference may occur in the favoring of certain plants due to the lack of competition as there may be faults in the experiment or by more aggressive genotypes that tend to have their performances overestimated once they compete with more sensitive genotypes (RESENDE et al., 2005). Progeny selection is also influenced, as the genetic effects may be underestimated or overestimated (RESENDE et al., 20l6).

Overall, two competition models can be used: the phenotypic model, when competition or interference does not have genetic control, thus, treating the neighbors phenotypic value as a covariate; and the genotypic model, when there is genetic control in the competition, relating the genetic effects of the neighbors to the residual value of the plant (RESENDE et al., 2005).

Genetic models of competition can be seen in Resende et al. (2016) testing intra-genotypic competition in Eucalyptus clones, Costa et al. (2013). Using simulated modeling data and Cappa and Cantet (2008) in P. taeda tests at 13 years of age using models that incorporate competition for both, genetic and non-genetic levels. Phenotypic models were studied by Leonardecz-Neto et al. (2003), who used Hegyi competition index for $\mathrm{DBH}$ data in several forest species and Pavan et al. (20I2), using besides this index other six covariates in Eucalyptus progenies tests for volume. The $\mathrm{DBH}$ and volume variables are more influenced by spacing and more susceptible to competition effects than the height (YE and JAYAWICKRAMA, 2008; STOEHR et al., $2010)$. Since $D B H$ is a readily available variable through direct measurement and because volume estimates are dependent on this variable, it is preferable to adjust phenotypic competition models for $\mathrm{DBH}$.

Thus, with the use of competition models, it is expected to isolate in a more efficient way the variation that occurs due to the environment, causing the analysis to express more consistently the experimental reality (LEONARDECZ-NETO et al., 2003). However, knowing which covariant and how it fits to faithfully represent, the biological effect, is often unknown (PAVAN et al., 20I2). One way to diagnose the presence of competition effects in field trials is from the residual correlation coefficient in which competition effects between neighboring plants cause negative autocorrelation and spatial heterogeneity causes positive correlations (RESENDE et al., 2005; CAPPA et al., 2016). Thus, the objective of the present work is to evaluate the efficiency of the phenotypic models of competition using four distinct covariates, through spatial analysis, in the genetic evaluation of a $P$. taeda progeny test.

\section{MATERIAL AND METHODS}

\section{Experimental area and genetic material}

The experimental area is located in two cities: Rio Negrinho and Lages in a plateau region of Santa Catarina state. The climate is classified as $\mathrm{Cfb}$ according to Köppen, subtropical humid with mild summer, without dry season (ALVARES et al., 2013). The regions present frost incidence in the colder months. Table I shows the other characteristics and location of the experiment.

The P. taeda L. genetic material comes from a $\left.\right|^{\text {st }}$ generation Clonal Orchard established in 1994, with material introduced from Georgia and Zimbabwe provenance, and from a seed production area with material from Zimbabwe provenance. The open pollinated progeny test was conducted in four different 
TABLE I Location and characterization of the experimental area of the P. taeda progeny test.

\begin{tabular}{ccccc}
\hline & SITE A & SITE B & SITE C & SITE D \\
\hline City & Rio Negrinho/SC & Rio Negrinho/SC & Rio Negrinho/SC & Lages/SC \\
\hline Altitude $(\mathrm{m})$ & 852 & 830 & 886 & 895 \\
Soil & Hapless Cambisol & Hapless Cambisol & Humic Cambisol & Humic Cambisol \\
Topography & Slightly Wavy & Strongly-wavy & Wavy & Slightly Wavy \\
Average precipitation $(\mathrm{mm})$ & 1876 & 1876 & 1876 & 1854 \\
Minimum Temperature $\left({ }^{\circ} \mathrm{C}\right)$ & 13.2 & 13.2 & 13.2 & 11.6 \\
Maximum temperature $\left({ }^{\circ} \mathrm{C}\right)$ & 22.1 & 22.1 & 22.1 & 21,2 \\
Average temperature $\left({ }^{\circ} \mathrm{C}\right)$ & 18.3 & 18.3 & 18.3 & 16.1 \\
\hline
\end{tabular}

environments (Sites A, B, C and D) and the installation occurred in 2006 in randomized block design with seven repetitions, six plant linear plots, in $2.5 \mathrm{~m} \times 2.0$ $\mathrm{m}$ spacing and double border rows. The test installed in sites $A, B$, and $D$ has 63 families and site $C 53$ families. The 53 families present at site $C$ are common to all sites. At the age of nine, a direct measurement of the variable Diameter at Breast height $(\mathrm{DBH}, \mathrm{cm})$ of all individuals at all progeny test sites was performed.

\section{Estimation of the spatial autocorrelation function}

The autocorrelation coefficients between residues following the direction of the rows or between columns $\left(\rho_{L}\right)$, following the direction of the columns or between rows $\left(\rho_{c}\right)$ and the value of the $d$ statistic for the DurbinWatson residue independence test were obtained using SELEGEN-REML / BLUP ${ }^{\circledR}$ software statistical model number I 3 (RESENDE, 2007a). The value of the statistic $d$ is defined as described in equation $I$, where $L$ is the order of the plot positioning in the experiment and $n$ refers to the residues as ordered in the space. The residues $\left(r_{i}\right)$ were obtained via model I SELEGEN - REML/BLUP® software (equation 3 ) considering zero in the analysis. The relation between $d$ and $\rho$ is given by equation 2 .

The calculated value of $d$ was compared with theoretical values with $(n-I)$ degrees of freedom, where $\mathrm{n}$ is the number of data. The calculated value of $d l$ (lower d) and du (upper d) are given in tables associated to certain significance levels. For hypothesis $\mathrm{Ha}: \rho>0$ the decision rule about $d$ is given by: if $d \leq d L$, it rejects $H_{0}$ and autocorrelation is positive; If $d \leq d u$, it accepts $H_{0}$ and the autocorrelation is null and if $d l<d<d u$ the test is inconclusive. For hypothesis $\mathrm{H}_{\mathrm{a}}: \rho<0$ the decision rule is equivalent, but using (4- $d$ ) instead of $d$ (RESENDE, 2007b).

$d=\sum_{i=1}^{n}\left(r_{i}-r_{i-1}\right)^{2} / \sum_{L=1}^{n} r_{i}^{2}$

$d=2(1-\rho)$

\section{Estimation of genetic parameters}

Genetic analysis of progeny tests were performed using SELEGEN - REML / BLUP® software. For the selection of individuals and progenies from in openpollinated parents, in the design used and performing the selection one site at a time, the statistical model I (equation 3) was used; and for the selection in the four sites (joint analysis) model 4 (equation 4) was used. In this model, $y$ is the vector of data, $r$ is the vector of the effects of repetition (assumed as fixed) added to the general mean; $a$ is the vector of the individual additive genetic effects (assumed as random); $p$ is the vector of plot effects (assumed as random); $i$ is vector of the effects of genotype $x$ environment interaction (random) and $\varepsilon$ is the vector of (random) errors or residues. Capital letters represent the incidence matrices for these effects (RESENDE, 2007a). For the estimates of the genetic parameters the zeros were not considered in the analysis.

$y=X r+Z a+W p+\varepsilon$

$y=X r+Z a+W p+T i+\varepsilon$

\section{Analysis of covariance}

The analysis of covariance of the progeny tests were performed with SELEGEN - REML / BLUP® software using statistical model I $3 \mathrm{I}$ (equation 5). In this, $y$ is the data vector; $r$ is the vector of the repetition effects (assumed as fixed values) added to the general mean; $a$ is the vector of the individual additive genetic effects (assumed as random), $p$ is the vector of the plot effects (assumed as random), $\varepsilon$ is the vector of (random) errors or residues. The coefficient $\beta$ refers to the regression associated with the covariate Cov Capital letters represent the incidence matrices for these effects (RESENDE, 2007a). For the analysis of covariance, zeros were not considered.

$y=X r+\beta \operatorname{Cov}+Z a+W p+\varepsilon$

The assumptions for analysis of covariance are: (I) the covariate values are fixed, measured without error and independent of the treatments. (II) The regression between the covariate and the variable of interest, after removal of block and treatment differences, is linear and independent of blocks and treatments. (III) The residue is normally and independently distributed, with zero mean 
and common variance (RESENDE, 2002; PALLANT, 20I0; RAMALHO et al., 20I2).

Three covariates were tested based on the performance of neighboring trees and one covariate based on the number of neighboring plants.

\section{Hegyi Competition Index (IC)}

Competition Mean (IC) through the distances and performance of the eight potential neighbors of the target plant $i$ (LEONARDECZ-NETO et al., 2003). The expression for the calculation is given by equation 6 , where $I C_{i}$ is the competition index of the target plant $i, Y_{i}$ is the observed value of the target plant $i ; Y_{j}$ is the observed value of competing plant $j$ and $D_{i j}$ is the distance between plants $i$ and $j$.

$I_{i}=\left(\sum_{j=1}^{8} Y_{j} / Y_{i}\right) / D_{i j}$

\section{Self-competition mean (MAT)}

Arithmetic mean of the silvicultural characteristic of the auto competitive trees (PAVAN et al., 2012), belonging to the same genetic material (equation 7), where $Y_{j}$ is the observed value of the self-competing plant $j$ and $n$ the number of auto competitive plants.

$$
\text { MAT }=\left(\sum_{j=1}^{2} Y_{j}\right) / n
$$

\section{Alo competition Mean (MAL)}

Arithmetic mean of the silvicultural characteristic of the alo competitive trees (PAVAN et al., 2012), belonging to different genetic material (equation 8), where $Y_{j}$ is the observed value of the alo competitive plant $j$ and $n$ the number of alo competitive plants.

$M A L=\left(\sum_{j=1}^{7} Y_{j}\right) / n$

\section{Number of neighboring plants (NV)}

Algebraic sum of the number of surviving neighboring plants (equation 9), where $n$ is the surviving neighboring plant (RESENDE, 2002).

$$
N V=\sum_{j=1}^{8}(n)
$$

\section{Adjustment of phenotypic values}

This is based on the covariance value of each individual $\left(x_{i j}\right)$, the mean value of the covariate $(\bar{X})$ and the residual regression coefficient $(\boldsymbol{\beta})$ between the covariate and the DBH data. The phenotypic values for each surviving individual were adjusted according to equation 10 for the covariates IC, MAT and MAL and equation II (RESENDE, 2002) for covariate NV, where $Y_{i j}$ is the phenotypic value measured for each individual and $Y_{i j c}$ the adjusted phenotypic value for each individual.

$Y_{i j c}=Y_{i j}-\beta\left(x_{i j}-\bar{x}\right)$

$Y_{i j c}=Y_{i j}-\beta\left(x_{i j}-8\right)$

\section{RESULTS AND DISCUSSION}

The major cause of the interference found in the four progeny tests was due to experiment failures, which caused absence of competition and the favoring of isolated individuals. At test site $A$ the favoring was intensified by the presence of three families that had much inferior performance to the others throughout the test. Mortality had genetic control for the tests at site $A$ and $C$ (TABLE 2). However, the competition effect was random in all tests, showing no tendency for either family.

TABLE 2 Deviance analysis for survival of $P$. taeda progenies at 9 years of age in Santa Catarina state.

\begin{tabular}{cc}
\hline Test site & LTR \\
\hline A & $105.49 *$ \\
B & $1.47^{\text {ns }}$ \\
C & $4.02^{*}$ \\
D & $2.37^{\text {ns }}$ \\
\hline
\end{tabular}

Where: LTR: likelihood ratio test; * And ns: significant and not significant at $5 \%$ by the chi-square test with I degree of freedom, respectively.

\section{Assumptions for analysis of covariates}

The residual regression coefficients $(\beta)$ for the covariates alo competition mean (MAL) and number of neighboring plants (NV) showed no interaction between covariate and $\mathrm{DBH}$ in any of the sites. The covariate selfcompetition mean (MAT) showed significant interaction between covariate $x$ treatment for sites $A, B$ and $D$. The same occurred for Hegyi competition index (IC) for site B. There was significance of the $\beta$ coefficients for all covariates, and these were negative for the covariates tested (TABLE 3).

As in Leonardecz-Neto et al. (2003) and Pavan et al. (20I2), for the covariates calculated based on the performance of neighboring trees, the assumptions for analysis of covariance are not satisfied in full, since they do not fully meet the first condition of the analysis of covariance. To minimize this implication, for covariates where residual regression coefficients that were not significant or showed no significant interaction with the treatments they were not used (TABLE 3). The same authors say that the use of indexes containing estimates and data-dependent errors should not be the only or the main concern for a reliable analysis. The proper 
TABLE 3 Residual regression coefficient $(\beta)$ between covariate and DBH data and mean value of covariate $(\overline{\mathrm{X}})$ in $P$. taeda progeny test in four test sites in the state of Santa Catarina.

\begin{tabular}{|c|c|c|c|c|c|c|c|c|}
\hline \multirow{2}{*}{$\begin{array}{l}\text { Covariate } \\
\text { Test site }\end{array}$} & \multicolumn{2}{|c|}{ IC } & \multicolumn{2}{|c|}{ MAT } & \multicolumn{2}{|c|}{ MAL } & \multicolumn{2}{|c|}{ NV } \\
\hline & $\beta$ & $\bar{x}$ & $\beta$ & $\overline{\mathrm{X}}$ & $\beta$ & $\overline{\mathrm{X}}$ & $\beta$ & $\overline{\mathbf{X}}$ \\
\hline A & $-4.15^{*}$ & 2.72 & - & - & $-0.31^{*}$ & 17.18 & $-0.11^{*}$ & 7.22 \\
\hline B & - & - & - & - & $-0.05^{\star}$ & 16.99 & $-0.19^{*}$ & 7.58 \\
\hline C & $-3.91^{*}$ & 2.87 & $-0.11^{*}$ & 17.57 & $-0.29^{*}$ & 17.52 & $-0.46^{*}$ & 7.47 \\
\hline $\mathrm{D}$ & $-3.99^{*}$ & 2.86 & - & - & $-0.19^{*}$ & 17.84 & $-0.39^{*}$ & 7.58 \\
\hline
\end{tabular}

*: Significant values at $5 \%$ probability. Where: IC: Hegyi competition index; MAT: self-competition mean; MAL: alo competition mean ; NV: number of neighboring plants; IC / MAL: combination of Hegyi competition index covariates and alo competition mean.

choice of the site for the allocation of the experiments, the reduction of the variance of the experimental and blocks errors are as or more important than the error associated with the covariate.

\section{Phenotypic models of competition for sites A and D}

For DBH data without adjustment, the coefficient of autocorrelation between residues following the direction of the columns $\left(\rho_{c}\right)$ was negative, significant and the statistic value $d$ was higher than two for sites $A$ and $D$. The same trend happened for the direction of the lines $\left(\rho_{L}\right)$ (TABLE 4). Negative and significant values of $\rho_{c}$ and $\rho_{L}$ are indicative of the presence of competition in the progeny tests studied, since competition effects between neighboring plants cause negative autocorrelation and $d$ statistic values greater than two. Spatial heterogeneity causes positive correlations (RESENDE et al., 2005; CAPPA et al., 2016).

The sites showed the same trend in progeny behavior after the covariate analysis. The coefficients $\rho_{c}$ and $\rho_{L}$ were negative and significant for sites $A$ and $D$ when the data were adjusted via NV covariate. This covariant practically did not alter the components of variance and genetic parameters when compared with the original data (TABLE 4). The adjustment using the covariate MAL presented negative and significant $\rho_{c}$, increase in $\sigma^{2}$, reduction in $\sigma_{f}^{2}$ and in $c^{2}$ parc . The value of this covariate considers only the competition among plots, thus not correcting intra-genotypic competition. The $\rho_{L}$ indicated absence of inter-genotypic competition, indicating that this covariate corrected the data between plots for the tests of sites $A$ and $D$, which can also be verified by the reduction in $\sigma_{\text {parc }}^{2}$ (TABLE4).

The covariate IC resulted in $\rho_{c}$ not significant and $\rho_{L}$ significant and positive, indicating absence of competition between lines and environmental heterogeneity between columns, respectively. Ye and Jayawickrama (2008) obtained average autocorrelation coefficients of 0.75 , indicating strong environmental variation, with environmental heterogeneity being the major source of interference in the progeny tests evaluated by the authors.

This environmental heterogeneity reflects changes in the variance components after the adjustment when compared to the original data, where there was a small increase in environmental variance between plots $\left(\sigma_{\text {parc }}^{2}\right)$ and a large reduction in individual phenotypic variance $\left(\sigma_{f}^{2}\right)$, resulting in an increase in the coefficient of determination of plot effects $\left(c^{2}{ }_{\text {parc }}\right)$ at both sites. The absence of correlation between the lines corresponds to an expressive reduction in the residual variance within the plot $\left(\sigma_{\mathrm{e}}^{2}\right)$ (TABLE 4). The reduction of $\sigma_{\text {parc }}^{2}$ and $\sigma^{2}{ }_{e}$ leads to an environmental improvement providing more reliable data for the selection process (PAVAN et al., 20I2). There was also a reduction in the additive genetic variance $\left(\sigma^{2}\right)$, that is, the adjusted data presented lower amplitude between the best and worst genetic material (TABLE 4). As in the work of Pavan et al. (20I2), the IC was the covariate that mostly altered the components of variance at sites $A, C$ and $D$, indicating great environmental influence on progeny tests due to competition between and within families.

Martinez et al. (20/2) obtained an individual heritability average $\left(h^{2}{ }_{a}\right)$ of close to 0.3 and $c^{2}$ parc considered as low magnitude. As mentioned in the work of Sturion and Resende (2005) it is considered as low $\mathrm{C}^{2}$ parc values lower than 0.10 for heritability values close to 0.30 . The test at site $A$, the adjusted IC data, presented a high value of $h^{2}{ }_{a}(0.42)$ and $c^{2}$ parc of 0.15 and a coefficient of residual variation $\left(\mathrm{CV}_{\mathrm{e}}\right)$ of $6 \%$, and site B showed moderate $h^{2}{ }_{a}(0.24)$ and $c^{2}$ parc of 0.23 and a residual coefficient of variation $\left(\mathrm{CV}_{\mathrm{e} \%}\right)$ of $5.5 \%$ (TABLE 4). Although $\mathrm{c}^{2}$ parc is slightly above recommended, the improvement in $\mathrm{CV}_{\mathrm{e}}$ and absence of competition effects justify the use of IC covariate in the selection for the two sites. 
TABLE 4 Variance components and genetic parameters, autocorrelation coefficients between residues in the directions of the lines $\left(\rho_{1}\right)$, columns $\left(\rho_{c}\right)$ and value of the statistic $d$ for rows and columns; with and without the use of covariates for DBH in a progeny test of $P$. taeda planted in two different sites in the state of Santa Catarina.

\begin{tabular}{|c|c|c|c|c|c|c|c|c|}
\hline & \multicolumn{4}{|c|}{ Site $A$} & \multicolumn{4}{|c|}{ Site $A$} \\
\hline & $\begin{array}{c}\text { Without } \\
\text { adjustment }\end{array}$ & IC & NV & MAL & $\begin{array}{c}\text { Without } \\
\text { adjustment }\end{array}$ & IC & NV & MAL \\
\hline$\sigma^{2} a$ & 7.34 & 2.28 & 7.30 & 4.10 & 3.00 & 0.79 & 3.01 & 2.71 \\
\hline$\sigma^{2}$ parc & 0.76 & 0.78 & 0.78 & 0.10 & 0.46 & 0.74 & 0.43 & 0.38 \\
\hline$\sigma^{2} e$ & 9.26 & 2.23 & 9.27 & 10.35 & 6.71 & 1.67 & 6.67 & 6.79 \\
\hline$\sigma^{2 f}$ & 17.36 & 5.29 & 17.35 & 14.55 & 10.17 & 3.20 & 10.11 & 9.89 \\
\hline$h^{2} a$ & $0.42 \pm 0.07$ & $0.43 \pm 0.08$ & $0.42 \pm 0.08$ & $0.28 \pm 0.08$ & $0.29 \pm 0.07$ & $0.25 \pm 0.06$ & $0.30 \pm 0.07$ & $0.27 \pm 0.07$ \\
\hline$c^{2}$ parc & 0.04 & 0.15 & 0.04 & 0.01 & 0.05 & 0.23 & 0.04 & 0.04 \\
\hline$h^{2} \mathrm{mp}$ & 0.80 & 0.74 & 0.80 & 0.75 & 0.70 & 0.51 & 0.70 & 0.69 \\
\hline Acprog & 0.89 & 0.86 & 0.89 & 0.87 & 0.83 & 0.72 & 0.84 & 0.83 \\
\hline$h^{2} a d$ & 0.37 & 0.43 & 0.37 & 0.23 & 0.25 & 0.26 & 0.25 & 0.23 \\
\hline CVgi\% & 13.63 & 7.65 & 13.67 & 10.08 & 8.91 & 4.57 & 9.00 & 8.47 \\
\hline $\mathrm{CVe} \%$ & 9.04 & 6.06 & 9.10 & 7.61 & 7.19 & 5.45 & 7.19 & 7.01 \\
\hline $\mathrm{CVr}$ & 0.75 & 0.63 & 0.75 & 0.66 & 0.60 & 0.42 & 0.63 & 0.60 \\
\hline $\mathrm{u}$ & 19.87 & 19.73 & 19.77 & 20.09 & 19.43 & 19.40 & 19.27 & 19.43 \\
\hline$\rho c$ & $-0.15^{*}$ & $0.00 \mathrm{~ns}$ & $-0.15^{*}$ & $-0.14 *$ & $-0.09 *$ & $0.02 \mathrm{~ns}$ & $-0.07^{*}$ & $-0.1 I^{*}$ \\
\hline d column & $2.30 *$ & $2.00 \mathrm{~ns}$ & $2.30 *$ & $2.28^{*}$ & $2.18^{*}$ & $1.95 \mathrm{~ns}$ & $2.15^{*}$ & $2.21 *$ \\
\hline$\rho \mathrm{L}$ & $-0.04 *$ & $0.09 *$ & $-0.04 *$ & $0.02 \mathrm{~ns}$ & $-0.06 *$ & $0.09 *$ & $-0.05 *$ & $-0.03 n s$ \\
\hline d row & $2.07 *$ & $1.8 \mathrm{I}^{*}$ & $2.07 *$ & $1.96 \mathrm{~ns}$ & $2.13 *$ & I.82* & 2.11* & $2.06 \mathrm{~ns}$ \\
\hline
\end{tabular}

* And ns: significant and non-significant values at $5 \%$ probability, respectively, by the Durbin-Watson test. Where: IC: Hegyi competition index; MAL: mean of the alo competition; NV: number of neighboring plants; $\sigma^{2}$ a: additive genetic variance; $\sigma^{2}$ parc: environmental variance between plots; $\sigma^{2} e$ : residual variance within the plot (environmental + non-additive genetics); $\sigma^{2} f$ individual phenotypic variance; $h^{2} a$ : individual heritability in the restricted sense; $c^{2}$ parc: coefficient of determination of plot effects; $h^{2} \mathrm{mp}$ : average progeny heritability; Acprog: accuracy of progeny selection; h2ad: additive heritability within plot; CVe\%: coefficient of residual variation; $\mathrm{CV}$ r: relative coefficient of variation; $\mathrm{u}=$ Average of the experiment.

\section{Phenotypic models of competition for sites B and $C$}

For the DBH data without adjustment, $\rho c$ was negative, significant and statistic value $d$ higher than two for sites B and $C$. The local B presented $\rho_{L}$ null, that is, absence of correlation and the negative and significant $C$ site (TABLE 5).

For the tests installed at these sites, the NV covariate corrected the data for the competition effects, presenting non-significant $\rho_{c}$ and $\rho_{L}$ and the genetic parameters were similar to the data set parameters without adjustment. The covariate MAL exhibited $\rho_{L}$ not significant and $\rho_{c}$ negative and significant, and that according to what occurred in sites $A$ and $D$, increase in $\sigma^{2}{ }_{e}$ and reduction in $\sigma_{\text {parc }}^{2}$. The same occurred with the use of this covariate at site C (TABLE 5).

The MAT covariate also corrected the data for the competition effects for site $\mathrm{C}$, provided increase in $\sigma^{2}$ parc reduction in $\sigma_{e}^{2}, \sigma_{f}^{2}$ and a slight increase in $c^{2}$ parc . For this location, two covariates corrected the data for competition effects with similar variance components, so the choice of the covariate to be used in the selection can be made based on the one that offers greater individual heritability $\left(h^{2}{ }_{a}\right)$, in the data set adjusted by MAT (TABLE 5).

The $C V_{e \%}$ remained the same or reduced in the tests in which the non-competition condition was met, showing that the data adjustment provided good experimental accuracy. As in the works of LeonardeczNeto et al. (2003), Ye and Jayawickrama (2008) and Pavan et al. (20I2), in general, coefficients of experimental variation were reduced with the use of covariates.

The values of individual heritability $\left(h^{2}\right)$, mean heritability of progenies $\left(h_{m p}^{2}\right)$, and additive heritability within plot $\left(h^{2}{ }_{a d}\right)$, were not significantly changed by analysis without adjustment or with adjustment by covariates (TABLE 5). Similar results were seen by Resende et al. (2005) testing several models of competition in experiment with Eucalyptus maculata. The author did not obtain reductions in the estimates of heritability between the traditional analysis and several models of competition tested, because in the dataset studied the competition was purely environmental.

\section{Individual selection results}

The genetic effects predicted for $\mathrm{DBH}$ using adjusted data suffered an intense reduction in site $A$ and a slightly smaller reduction for site $D$, that is, gains on selection would be overestimated for these sites. For these sites, only eight individuals in the ranking of the twenty with the highest genetic values are present in both sets of data (TABLE 6). Some individuals which would be selected without data adjustment, mainly the closest to the gaps, were no longer selected after data adjustment. However, 
TABLE 5 Parameters estimates of the omnidirectional and cross semivariograms Vol = volume, Exp = Exponential.

\begin{tabular}{|c|c|c|c|c|c|c|c|c|}
\hline & \multicolumn{3}{|c|}{ Site B } & \multicolumn{5}{|c|}{ Site C } \\
\hline & $\begin{array}{c}\text { Without } \\
\text { adjustment }\end{array}$ & NV & MAL & $\begin{array}{c}\text { Without } \\
\text { adjustment }\end{array}$ & IC & MAT & NV & MAL \\
\hline$\sigma^{2} a$ & 3.59 & 3.51 & 3.41 & 3.09 & 0.58 & 3.18 & 2.87 & 2.20 \\
\hline$\sigma^{2}$ parc & 0.24 & 0.26 & 0.22 & 0.05 & 0.67 & 0.32 & 0.05 & 0.04 \\
\hline$\sigma^{2} e$ & 7.74 & 7.77 & 8.04 & 12.04 & 2.86 & 8.42 & 12.13 & 12.35 \\
\hline$\sigma^{2 f}$ & 11.57 & 11.54 & 11.67 & 15.18 & 4.11 & 11.92 & 15.04 & 14.59 \\
\hline$h^{2} a$ & $0.31 \pm 0.06$ & $0.30 \pm 0.06$ & $0.29 \pm 0.06$ & $0.20 \pm 0.06$ & $0.14 \pm 0.05$ & $0.26 \pm 0.07$ & $0.19 \pm 0.05$ & $0.15 \pm 0.05$ \\
\hline$c^{2}$ parc & 0.02 & 0.02 & 0.02 & 0.00 & 0.16 & 0.03 & 0.00 & 0.00 \\
\hline$h^{2} \mathrm{mp}$ & 0.76 & 0.76 & 0.75 & 0.69 & 0.46 & 0.72 & 0.67 & 0.62 \\
\hline Acprog & 0.87 & 0.87 & 0.87 & 0.83 & 0.67 & 0.85 & 0.82 & 0.79 \\
\hline$h^{2} \mathrm{ad}$ & 0.26 & 0.25 & 0.24 & 0.16 & 0.13 & 0.22 & 0.15 & 0.12 \\
\hline $\mathrm{CVe} \%$ & 7.72 & 7.72 & 7.75 & 8.31 & 5.84 & 7.56 & 8.39 & 8.19 \\
\hline $\mathrm{CVr}$ & 0.67 & 0.66 & 0.65 & 0.56 & 0.35 & 0.61 & 0.54 & 0.48 \\
\hline $\mathrm{u}$ & 18.22 & 18.14 & 18.21 & 18.81 & 18.91 & 19.25 & 18.56 & 18.81 \\
\hline$\rho c$ & $-0.18^{*}$ & $-0.04 n s$ & $-0.19 *$ & $-0.06 *$ & $0.06 *$ & $-0.02 n s$ & $-0.04 n s$ & $-0.07^{*}$ \\
\hline d column & $2.37 *$ & $2.07 \mathrm{~ns}$ & $2.37 *$ & $2.12 *$ & I.87* & $2.05 \mathrm{~ns}$ & $2.07 \mathrm{~ns}$ & $2.13^{*}$ \\
\hline$\rho \mathrm{L}$ & $0.00 \mathrm{~ns}$ & $0.0 \mathrm{Ins}$ & $0.00 \mathrm{~ns}$ & $-0.06 *$ & $0.11 *$ & $0.00 \mathrm{~ns}$ & $-0.03 n s$ & $0.00 \mathrm{~ns}$ \\
\hline d row & $2.00 \mathrm{~ns}$ & $1.98 \mathrm{~ns}$ & $2.00 \mathrm{~ns}$ & 2.12* & I.78* & $2.00 \mathrm{~ns}$ & $2.07 \mathrm{~ns}$ & $1.99 \mathrm{~ns}$ \\
\hline
\end{tabular}

* And ns: significant and non-significant values at $5 \%$ probability, respectively, by the Durbin-Watson test. Where: IC: Hegyi competition index; MAL: mean of the alo competition; NV: number of neighboring plants; $\sigma^{2}$ a: additive genetic variance; $\sigma^{2}$ parc: environmental variance between plots; $\sigma^{2} e$ : residual variance within the plot (environmental + non-additive genetics); $\sigma^{2}$ f: individual phenotypic variance; $h^{2} a$ : individual heritability in the restricted sense; $c^{2}$ parc: coefficient of determination of plot effects; $h^{2} \mathrm{mp}$ : average progeny heritability; Acprog: accuracy of progeny selection; $h^{2}$ ad: additive heritability within plot; $C V e \%$ : coefficient of residual variation; $\mathrm{CV}$ : relative coefficient of variation; $\mathrm{u}=$ Average of the experiment.

some individuals which were selected previously the adjustment of data and that were not close to the gaps, remained in the selection (FIGURE I).

For site $B$ there was a small reduction in the genetic effect and in site $C$ the adjustment for the effects of competition increased the value of the predicted genetic effect. At site B only $5 \%$ of individuals are not the same for the set and unadjusted data sets and at site C $30 \%$ (TABLE 7). In this way, genetic materials have

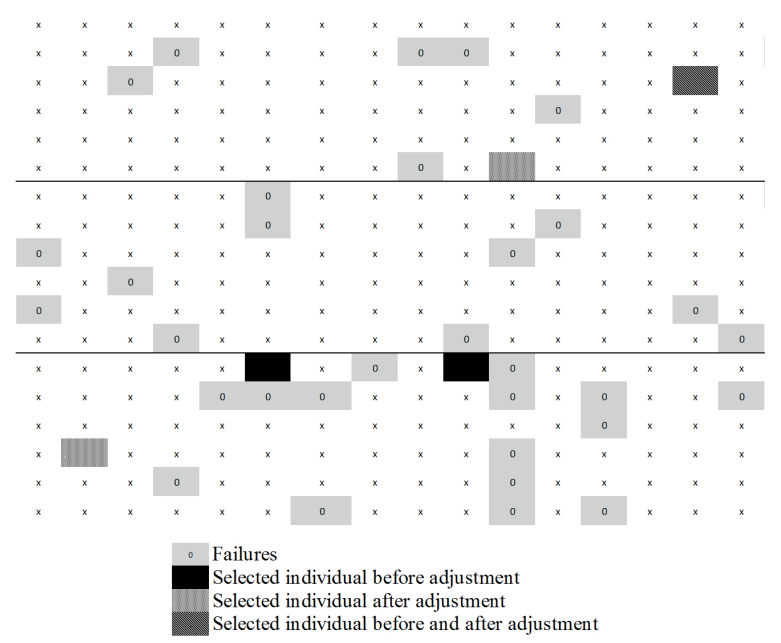

FIGURE I Detail of the progenies test installed on the site A which demonstrates the individuals that would be selected before the adjustment, after the adjustment and which remains selected after the data adjustment. different responses to bioclimatic conditions, and may have different aptitudes, with some presenting or not increased growth, due to the lack of competition caused by the failure of neighboring plants (PAVAN et al., 2012).

\section{Correlation among sites}

The variance components and genetic parameters for joint analysis, considering all four sites, were estimated for $\mathrm{DBH}$ data with and without adjustment (TABLE 8). The value of $h^{2}$ for the unadjusted data set was higher than for the adjusted data (TABLE 8), since the estimation of the average individual heritability in the restricted sense in the environment is influenced by the genotype $x$ environment interaction.

Genetic correlation between progeny performance in the four environments was high $(0.80)$ for unadjusted $\mathrm{DBH}$ data, the same value found in P. taeda tests at four sites (distributed in the cities Otacílio Costa / SC And Telêmaco Borba ( PR) in the research presented by Martinez et al. (2012). As in the above, the variance of the genotype $x$ environment interaction was of low magnitude $(0.2 \mathrm{I})$, which resulted in a low coefficient of determination for the effects of genotype $x$ environment interaction (0.03). For the adjusted $\mathrm{DBH}$ data, the correlation between the four sites was low (0.52), indicating loss in gain from performing selection at one site for use in distinct locations, as the best individuals in the environment may not be in another one (RESENDE, 2007b) (TABLE 8). 
TABLE 6 Classification of the twenty best individuals by genetic effects for $\mathrm{DBH}$ in a progeny test of $P$. taeda planted at two sites in the state of Santa Catarina.

\begin{tabular}{|c|c|c|c|c|c|c|c|c|c|c|c|c|c|c|c|}
\hline \multicolumn{4}{|c|}{$\begin{array}{c}\text { Site } \mathrm{A} \\
\text { without adjustment }\end{array}$} & \multicolumn{4}{|c|}{$\begin{array}{c}\text { Site } A \\
\text { with adjustment }\end{array}$} & \multicolumn{4}{|c|}{$\begin{array}{c}\text { Site D } \\
\text { without adjustment }\end{array}$} & \multicolumn{4}{|c|}{$\begin{array}{c}\text { Site D } \\
\text { with adjustment }\end{array}$} \\
\hline $\mathrm{BL}$ & FAM & ARV & $\mathrm{a}$ & $\mathrm{BL}$ & FAM & ARV & $\mathrm{a}$ & $\mathrm{BL}$ & FAM & ARV & $\mathrm{a}$ & $\mathrm{BL}$ & FAM & ARV & $\mathrm{a}$ \\
\hline 2 & 40 & 4 & 6.018 & 3 & 27 & 3 & 3.249 & I & 18 & 3 & 3.821 & I & 60 & 2 & 2.283 \\
\hline 3 & 27 & 3 & 5.098 & I & 46 & 2 & 2.808 & I & 60 & 2 & 3.716 & I & 8 & 5 & 2.234 \\
\hline 2 & 34 & I & 5.063 & 6 & 29 & 1 & 2.780 & I & 12 & 3 & 3.492 & I & 12 & 3 & 2.029 \\
\hline 4 & 43 & 2 & 4.778 & 3 & 34 & 3 & 2.714 & 4 & 33 & 3 & 3.077 & 6 & 60 & 5 & 1.686 \\
\hline 5 & 42 & 6 & 4.732 & 1 & 19 & 3 & 2.671 & I & 18 & 5 & 3.023 & I & 18 & 3 & I.534 \\
\hline 4 & 61 & 6 & 4.633 & 4 & 46 & 3 & 2.651 & 3 & 38 & I & 2.992 & 6 & 42 & 5 & 1.480 \\
\hline 6 & 29 & I & 4.462 & I & 27 & 3 & 2.644 & 6 & 60 & 5 & 2.916 & 2 & 19 & 6 & 1.455 \\
\hline 5 & 40 & I & 4.446 & 2 & 34 & I & 2.625 & 6 & 42 & 5 & 2.856 & 4 & 33 & 3 & 1.437 \\
\hline 3 & 34 & 3 & 4.405 & 7 & 15 & 2 & 2.622 & 2 & 19 & 6 & 2.789 & 3 & 38 & I & 1.418 \\
\hline 5 & 43 & I & 4.363 & 2 & 18 & 5 & 2.573 & I & 38 & 6 & 2.696 & 5 & 51 & 3 & 1.350 \\
\hline 2 & 47 & 4 & 4.269 & 3 & 47 & 6 & 2.570 & 2 & 42 & 4 & 2.653 & 6 & 38 & 2 & 1.317 \\
\hline I & 40 & 6 & 4.206 & 6 & 34 & 4 & 2.556 & 6 & 27 & I & 2.582 & I & 29 & 5 & 1.313 \\
\hline I & 27 & 3 & 4.201 & 4 & 43 & 2 & $2.54 I$ & 5 & 42 & I & 2.472 & 3 & 42 & 4 & 1.309 \\
\hline 6 & 59 & I & 4.178 & 3 & 15 & I & 2.454 & I & 38 & 4 & 2.458 & I & 9 & 5 & 1.280 \\
\hline 2 & 18 & 5 & 4.141 & 7 & 21 & 4 & 2.448 & I & 29 & I & 2.454 & I & 38 & 4 & 1.277 \\
\hline 2 & 34 & 3 & 4.131 & I & 34 & 2 & 2.443 & 4 & 38 & 4 & 2.450 & I & 38 & 6 & 1.274 \\
\hline 5 & 31 & I & 4.125 & 7 & 61 & 1 & 2.438 & 4 & 42 & 3 & 2.429 & I & 13 & 4 & I.27I \\
\hline 5 & 50 & 5 & 4.108 & 5 & 18 & 4 & 2.433 & 4 & 60 & 2 & 2.403 & 6 & 38 & 5 & 1.244 \\
\hline 7 & 56 & 4 & 4.051 & 4 & 34 & I & 2.429 & I & 42 & 5 & 2.371 & 2 & 63 & 4 & 1.214 \\
\hline 7 & 34 & 6 & 4.034 & 4 & 61 & 6 & 2.417 & 6 & 38 & 4 & 2.344 & 5 & 30 & 4 & 1.208 \\
\hline
\end{tabular}

Where: BL: block; FAM: family; ARV: tree; A: predicted genetic effect.

TABLE 7 Classification of the twenty best individuals by genetic effects for $\mathrm{DBH}$ in a progeny test of $P$. taeda planted in two sites in the state of Santa Catarina.

\begin{tabular}{|c|c|c|c|c|c|c|c|c|c|c|c|c|c|c|c|}
\hline \multicolumn{4}{|c|}{$\begin{array}{c}\text { Site B } \\
\text { without adjustment }\end{array}$} & \multicolumn{4}{|c|}{$\begin{array}{c}\text { Site B } \\
\text { with adjustment }\end{array}$} & & \multicolumn{3}{|c|}{$\begin{array}{c}\text { Site C } \\
\text { without adjustment }\end{array}$} & \multicolumn{4}{|c|}{$\begin{array}{c}\text { Site C } \\
\text { with adjustment }\end{array}$} \\
\hline$B L$ & FAM & ARV & $a$ & $\mathrm{BL}$ & FAM & ARV & $\mathrm{a}$ & $\mathrm{BL}$ & FAM & ARV & $a$ & $B L$ & FAM & ARV & $a$ \\
\hline 7 & 38 & 4 & 3.926 & 7 & 38 & 4 & 3.874 & 4 & 42 & 3 & 3.190 & I & 52 & 6 & 3.508 \\
\hline 5 & 17 & 6 & 3.565 & 6 & 38 & 3 & 3.540 & 7 & 42 & I & 2.992 & 4 & 42 & 3 & 3.339 \\
\hline 6 & 38 & 3 & 3.550 & 5 & 17 & 6 & 3.480 & I & 42 & 3 & 2.990 & I & 42 & 3 & 3.191 \\
\hline 4 & 59 & 5 & 3.442 & 4 & 59 & 5 & 3.278 & 3 & 42 & 4 & 2.890 & 7 & 27 & 6 & 3.152 \\
\hline 6 & 60 & 6 & 3.427 & 6 & 60 & 6 & 3.270 & 2 & 42 & 6 & 2.857 & 3 & 42 & 4 & 3.091 \\
\hline 6 & 38 & 2 & 3.305 & 6 & 38 & 2 & 3.261 & 6 & 42 & 4 & 2.832 & 7 & 42 & I & 3.061 \\
\hline 6 & 39 & 3 & 3.297 & 6 & 39 & 3 & 3.236 & 2 & 42 & 2 & 2.805 & 2 & 42 & 2 & 3.021 \\
\hline 5 & 38 & 3 & 3.250 & 6 & 38 & 5 & 3.211 & I & 52 & 6 & 2.758 & 7 & 35 & I & 3.007 \\
\hline 6 & 38 & 5 & 3.222 & 5 & 38 & 3 & 3.190 & 7 & 35 & I & 2.746 & 6 & 42 & 4 & 2.983 \\
\hline 5 & 43 & I & 3.159 & 2 & 38 & 6 & 3.150 & 7 & 35 & 6 & 2.694 & 7 & 35 & 6 & 2.963 \\
\hline 2 & 38 & 6 & 3.140 & 5 & 43 & I & 3.100 & 6 & 42 & 6 & 2.677 & 4 & 45 & 5 & 2.893 \\
\hline 3 & 38 & 4 & 2.972 & 3 & 38 & 4 & 2.991 & 7 & 42 & 3 & 2.631 & I & 48 & I & 2.863 \\
\hline 4 & 38 & 2 & 2.965 & 4 & 38 & 2 & 2.975 & 4 & 45 & 5 & 2.616 & 6 & 42 & 6 & 2.762 \\
\hline I & 42 & I & 2.938 & 6 & 26 & 6 & 2.919 & 7 & 27 & 6 & 2.577 & 2 & 27 & 3 & 2.756 \\
\hline 6 & 26 & 6 & 2.906 & 7 & 42 & 6 & 2.890 & I & 48 & I & 2.506 & 7 & 42 & 3 & 2.663 \\
\hline 7 & 42 & 6 & 2.899 & I & 42 & I & 2.878 & 6 & 42 & 2 & 2.420 & 2 & 52 & 6 & 2.592 \\
\hline 5 & 42 & 4 & 2.898 & 2 & 38 & 3 & 2.820 & 5 & 42 & 5 & 2.405 & 2 & 42 & 6 & 2.580 \\
\hline 5 & 33 & 2 & 2.827 & 5 & 33 & 2 & 2.809 & 7 & 42 & 6 & 2.374 & 6 & 27 & 5 & 2.569 \\
\hline 7 & 29 & 4 & 2.813 & 7 & 29 & 4 & 2.800 & I & 42 & I & 2.271 & 7 & 27 & 3 & 2.555 \\
\hline 2 & 38 & 3 & 2.812 & I & 38 & 4 & 2.760 & 3 & 42 & 3 & 2.221 & 5 & 27 & 6 & 2.540 \\
\hline
\end{tabular}

Where: BL: block; FAM: family; ARV: tree; A: predicted genetic effect

It is emphasized that if the data were not corrected for the competition effect, only one breeding zone for the tested sites would erroneously be established. When correcting the data for competition effects, for better efficiency of indirect gains, two breeding areas should be established, ne for test sites $B$ and $C$ and another for sites $A$ and $D$ (TABLE 9).

\section{CONCLUSION}

The phenotype models of competition using covariates are efficient for correcting the data for competition effects. The covariate IC was more efficient for the test at sites $A$ and $D$, the covariate NV for the test at site $B$ and the covariate MAT for the test site $C$. That 
TABLE 8 Variance components and genetic parameters estimated by joint analysis for $\mathrm{DBH}$ in a progeny test of $P$. taeda planted in four sites in the state of Santa Catarina.

\begin{tabular}{ccc}
\hline $\begin{array}{c}\text { Parameter/Var. } \\
\text { component. }\end{array}$ & Ajusted joint analysis $\begin{array}{c}\text { Joint analysis without } \\
\text { adjustment }\end{array}$ \\
\hline$\sigma^{2} \mathrm{a}$ & 4.26 & 0.93 \\
$\sigma^{2}$ parc & 0.32 & 0.44 \\
$\sigma^{2} \mathrm{e}$ & 8.27 & 6.34 \\
$\sigma^{2} \mathrm{f}$ & 13.11 & 7.92 \\
$\mathrm{~h}^{2} \mathrm{a}$ & 0.32 & 0.12 \\
$\mathrm{c}^{2}$ parc & 0.02 & 0.06 \\
$\mathrm{~h}^{2} \mathrm{mp}$ & 0.87 & 0.66 \\
Acprog & 0.93 & 0.82 \\
$\mathrm{~h}^{2} \mathrm{ad}$ & 0.28 & 0.10 \\
$\mathrm{u}$ & 19.07 & 19.16 \\
\hline
\end{tabular}

Where: $\sigma 2 \mathrm{a}$ : additive genetic variance; $\sigma^{2}$ parc: environmental variance between plots; $\sigma^{2}$ e: residual variance within the plot (environmental + non-additive genetics); $\sigma^{2}$ : individual phenotypic variance; $h^{2} a$ : individual heritability in the restricted sense; $c^{2}$ parc: coefficient of determination of plot effects; $h^{2} \mathrm{mp}$ : average progeny heritability; $h^{2}$ ad: additive heritability within plot; $u=$ average of the experiment; Acprog: accuracy of progeny selection.

TABLE 9 Genetic correlation between sites and heritabilities estimated by means of joint analysis for $\mathrm{DBH}$ in a progeny test of $P$. taeda in the state of Santa Catarina.

$\begin{array}{ccc}\text { Site } & \text { Genetic correlation } & h^{2} a \\ \text { A e D } & 0.8 \mathrm{I} & 0.13\end{array}$

$\begin{array}{lll}B \text { e C } & 0.75 & 0.19\end{array}$

A, B e C $\quad 0.61 \quad 0.14$

$B, C$ e D $\quad 0.53 \quad 0.12$

$A$ e B $\quad 0.51 \quad 0.11$

$\begin{array}{lll}A \text { e } C & 0.50 & 0.12\end{array}$

A, C e D $\quad 0.48 \quad 0.10$

$\begin{array}{lll}\text { C e D } & 0.33 & 0.08\end{array}$

$B$ e $D$

0.24

0.05

$\mathrm{H}^{2} \mathrm{a}$ : individual heritability in the restricted sense obtained by the joint analysis.

is, there is not a single model that fits all locations, making it necessary to examine individually which covariate best fits the data set based on autocorrelation coefficients and variance components.

The residual autocorrelation coefficient and Durbin-Watson test can be used to identify the presence or absence of competition in P. taeda progeny tests and the effectiveness of the covariate used in the model.

The use of these two tools is of great importance in the analysis of data in $P$. taeda progeny tests, since there is a great discrepancy in the individual classification of the progenies, in the genotypic effects and in the definition of breeding areas between the unadjusted data and the adjusted for the effects of competition.

\section{ACKNOWLEDGMENT}

We thank CAPES / CNPQ for the financial support, Mobasa Reforestation S / A and the Laboratory of Genetics and Forest Improvement of UFPR.

\section{REFERENCES}

ALVARES, C. A.; STAPE, J. L.; SENTELHAS, P. C.; de MORAES, G.; LEONARDO, J.; SPAROVEK, G. Köppen's climate classification map for Brazil. Meteorologische Zeitschrift, v. 22, n. 6, p. 7II-728, 2013.

CAPPA, E. P.; CANTET, R. J. Direct and competition additive effects in tree breeding: Bayesian estimation from an individual tree mixed model. Silvae Genetica, v. 57 , n. 2 , p. $45-55,2008$.

CAPPA, E. P., STOEHR, M. U., XIE, C. Y., \& YANCHUK, A. $D$. Identification and joint modeling of competition effects and environmental heterogeneity in three Douglas-fir (Pseudotsuga menziesii var. menziesii) trials. Tree Genetics \& Genomes, v. 12, n. 6, p. 102, 2016.

COSTA, J. S.; KERR, R. Accounting for competition in genetic analysis, with particular emphasis on forest genetic trials. Tree Genetics \& Genomes, v. 9, n. , p. I-17, 2013.

LEONARDECZ-NETO, E.; VENCOVSKY, R.; SEBBENN, A. M. Ajuste para a competição entre plantas em teste de progênies e procedências de essências florestais. Scientia Forestalis, n. 63, p. I36-149, 2003.

MARTINEZ, D.T.; RESENDE, M. D. V.; COSTA, R. B. da; HIGA, A. R.; SANTOS, G. A. dos; FIER, I. S. N. Estudo da interação genótipo $x$ ambiente em progênies de Pinus taeda por meio da análise de parâmetros genéticos. Floresta, v. 42, n. 3, p. 539 - 552, 2012.

PALLANT, J. SPSS survival manual: A step by step guide to data analysis using SPSS. Maidenhead, 2010. $354 \mathrm{p}$.

PAVAN, B. E.; DE PAULA, R. C.; PERECIN, D.; CANDIDO, L. S.; SCARPINATI, E. A. Efeito competicional em testes de progênies de eucalipto. Ciência Florestal, v. 22, n. 3, p. 433-443, 2012.

RAMALHO, M. A. P.; FerReiRA, D. F.; OliveirA, A. C. Experimentação em genética e melhoramento de plantas. $3^{\mathrm{a}}$ Ed. Lavras: Editora UFLA, 2012. 305 p.

RESENDE, M. D. V. Genética biométrica e estatística no melhoramento de plantas perenes. Brasília: Embrapa. Informação Tecnológica, 2002. 975p.

RESENDE, M. D. V. Selegen-Reml/Blup: Sistema Estatístico e Seleção Genética Computadorizada via Modelos Lineares Mistos. Colombo: Embrapa Florestas, 2007a. 36 I p.

RESENDE, M.D. V. Matemática e estatística na análise de experimentos e no melhoramento genético. Colombo: Embrapa Florestas, 2007b. 362p.

RESENDE, M.D. V.; STRINGER, J.; CULLIS, B.; THOMPSON, R. joint modelling of competition and spatial variability in forest field trials. Revista Matemática e Estatística, v.23, n.2, p.7-22, 2005. 
RESENDE, R. T.; MARCATTI, G. E.; PINTO, D. S.; TAKAHASHI, E. K.; CRUZ, C.D.; RESENDE, M. D. V. Intra-genotypic competition of Eucalyptus clones generated by environmental heterogeneity can optimize productivity in forest stands. Forest Ecology and Management, v. 380, p. 50-58, 2016.

STOEHR, M.; BIRD, K.; NIGH, G.; WOODS, J.; YANCHUK, A. Realized genetic gains in coastal Douglas-fir in British Columbia: implications for growth and yield projections. Silvae Genetica, v. 59, n. 5, p. 223-233, 2010.
STURION, J. A. e RESENDE, M. D. V. Eficiência do delineamento experimental e capacidade de teste no melhoramento genético da erva-mate (Ilex paraguariensis St. Hil). Pesquisa Florestal Brasileira, n. 50, p. 3-10, 2005.

YE, T. Z.; JAYAWICKRAMA, K. J. S. Efficiency of using spatial analysis in first-generation coastal Douglas-fir progeny tests in the US Pacific Northwest. Tree Genetics \& Genomes, v. 4, n. 4, p. 677-692, 2008. 